\title{
Making sense of the senseless
}

\author{
Six Months in Sudan: A Young Doctor in a \\ War-torn Village \\ James Maskalyk \\ Doubleday Canada; 2009. \\ $352 \mathrm{pp} \$ 29.95$
}

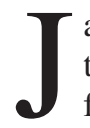

ames Maskalyk is a fool. But in the finest tradition of the wise fool, he challenges and asks questions as he shares the story of his seemingly tireless work with Médecins Sans Frontières in war-torn Abyei, in the hope of building a more certain future. Yet, as he left, the town was on fire, the war had escalated, and the bodies and dwindling supplies had overwhelmed local staff. "We were supposed to save that place, all of us," ends his haunting memoir Six Months in Sudan.

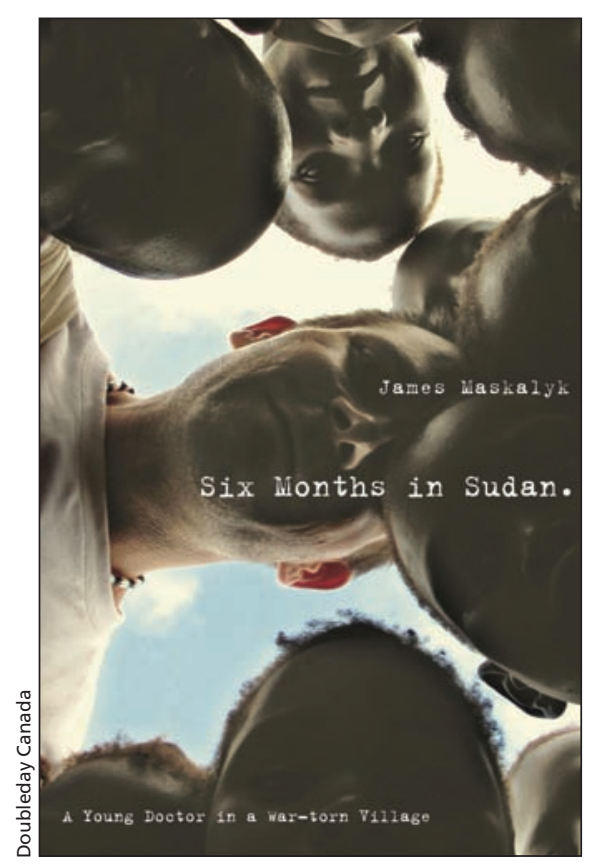

Against incredible odds, Maskalyk's exuberance for life cascades across the pages; he imagines the smile that will "burn like a star" on his mother's face when he returns; revels in his quest for the perfect, coolest pair of sunglasses; is overjoyed at being able to use MSF's radios and say "good copy. Over and out." He leaves magic tricks and glowin-the-dark armbands for the malnour- ished kids. After 6 months of feeling the lives of so many people slip through his fingers - casualties of measles, pneumonia, malaria, gunshot wounds, obstructed labour, starvation, HIV and tuberculosis - he is the kind of man who is greeted on his arrival home in Toronto by a friend who, as a joke, had dressed up in a mullet wig, white tank top and powder blue pants 3 inches too short.

Maskalyk is an award-winning clinical teacher in Toronto. In this book he is another kind of teacher, one who shares himself openly in this very real story that grew out of the blog he posted on the MSF website while he was in Sudan. The book seamlessly alternates voices from the blog, to his lyrical narrative:

" $i$ don't think that $i$ will end up ruined, but there are going to be certain things that are going to be tough to share. things that would make poor dinner conversation (hey, have you ever heard an infant's heart stop?)

"the best things $\mathrm{i}$ will have left behind are not the ones that can be summarized in my end-of-mission report. they are the bright beautiful parts of the day that can only be lived here. there are many. i will miss them."

And like every good teacher, he asks questions he doesn't answer. Maskalyk states it is the mandate of MSF to practise secondary care, to delegate problems that could be managed at the primary care level to nongovernmental organizations, such as Irelandbased GOAL, even when the community led by its paramount chiefs expressed dissatisfaction with this way of working. Why then did MSF organize its own measles vaccination campaign? Why did it bring in its own emergency team, and hire and train its own vaccinators? Why was there no mention of collaboration with the Ministry of Health (which later complained) or of the paramount chiefs (who could have helped mobilize the community) or of GOAL, except to mention their statistics which might not be any good? Maybe they were

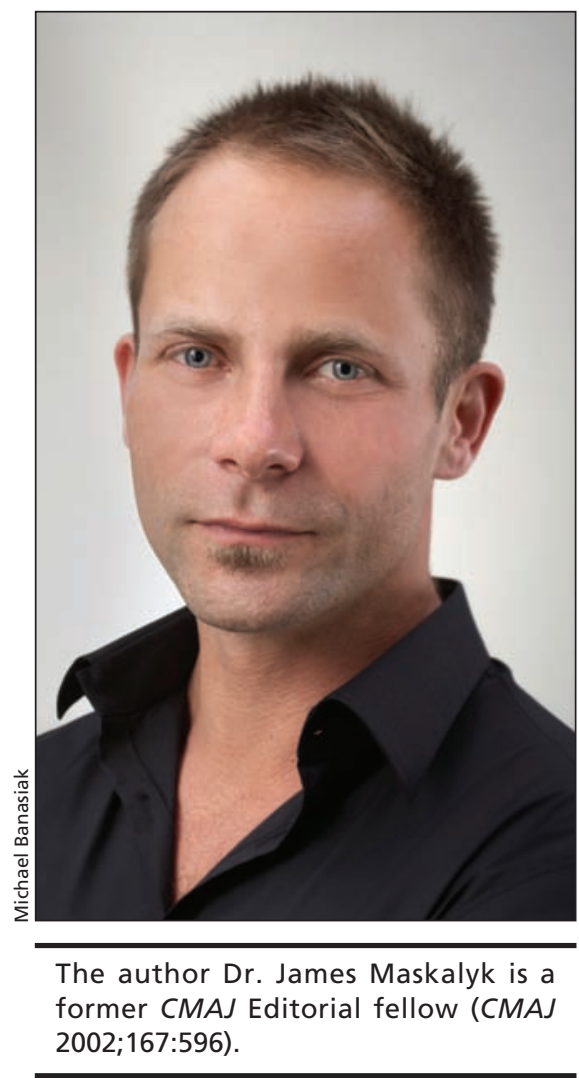

there, but not mentioned, maybe these other partners also helped interface with the community to follow up the tuberculosis patients as well, but were not recorded.

It caused me to reflect on his own answer, "Each time we are a band-aid we simply cover the problem and delay the slow work towards a tenable, permanent solution."

This is the kind of book that makes sense of the senseless and builds important connections between those who have seen and felt what he has, those who aspire to do this kind of work, those who want to support the dedicated humanitarian service of others and those who just want to understand. He writes: "good copy. over and out. for real. so sweet."

\section{Gretchen Roedde MD}

Family physician

International reproductive health care consultant

Temiskaming Shores, Ont. 